\title{
Adapting conventional delivery to cope with large cohorts: turning seminars into workshops and changing assessment
}

\author{
Simon Sweeney \\ University of York, United Kingdom.
}

\begin{abstract}
Teaching a popular postgraduate political economy module to around 50 international business and environment students (mainly Chinese) had always gone well. Delivery consisted of lectures and seminars with assessment via a 3,000-word essay. But with a three times larger cohort in 2017 things went wrong. The response from the teaching team was twofold. First to replace seminars with team-taught 2-hour workshops, to provide fewer targeted readings accompanied by specific questions for groups to answer, plus a redesign of the assessment, introducing a shorter more issuespecific approach based on short (500-word) answers to five questions chosen from ten, all tied to module learning outcomes and content. How did all this go? The paper highlights problems with the traditional approach and offers an initial evaluation of the changes introduced in 2018. Ultimately the paper addresses the strengths and weaknesses of the before and after and relates this to the changing demands placed on tutors charged with teaching large cohorts in a department going through rapid expansion. The case highlights the critical balance between volume and quality and asks difficult questions about the student experience and how universities respond to an increasingly marketized higher education sector.
\end{abstract}

Keywords: lectures; seminars; workshops; assessment; marketisation; student experience. 


\section{Introduction - why things are as they are}

This paper confronts a critical challenge facing universities and even within single departments experiencing rapid growth in an era of marketisation that is bringing dramatic change to the higher education sector (Jongloed, 2003; Brown and Carasso, 2013). Marketization means reliance on income from student fees, especially higher paying international students, and an environment in which universities' autonomy means operating in a commercially competitive environment within which some departments may be deemed not viable while others are substantial revenue earners. The importance of secure income streams from teaching has commercialised the sector (Molesworth, et al, 2009, 2011; Collini, 2011; Nixon, et al. 2016). Government extolls the economic benefits of higher education above educational or cultural values (HM Government, 2011; Warner, 2015). For some years now and especially since the Browne Review into Higher Education (HM Government, 2010), there has been an emphasis on objectives around employment, investment, and competitiveness. Education is required to articulate with the Neoliberal ideology that drives contemporary economic globalisation (Lynch, 2006; Gray, 2010). At all levels education also appears to degrade creativity in its obsession with outcomes and qualifications, as Sir Ken Robinson famously claimed more than a decade ago (Robinson, 2006). He was talking about schools, but much of higher education reflects the same process.

Students have become consumers of a product in a process of commodification that has fuelled competition and rivalry between institutions including new private providers (HM Government, 2016). While many academics interpret internationalization as comprising mobility across borders, collaborative research, sharing cultural capital and appreciating the value of diversity and cosmopolitanism as a public good (Knight, 1994, 2003; Fielden, 2007; Sweeney, 2012) university accountants and financial controllers see internationalization strategies as primarily about attracting more overseas students and research grants from abroad. HEIs focus recruitment on lucrative markets such as China, India and the Gulf. This is relevant to the case reported in this article, because the module concerned is taught in a School that fits the marketisation/commodification thesis.

The case reported here describes direct experience regarding one module in a UK Russell Group institution where the management/business school provides significant income from postgraduate courses, income which serves to subsidise other departments with much smaller intake of overseas students. This is a common situation in many universities. International students make up a high proportion of postgraduate fees income, especially in certain disciplines: business and management foremost among these. 
The paper begins with a brief discussion concerning student engagement (SE) and how even this has become a contested concept. I will then present a case study involving a single module on international political economy and business, taught in York Management School. The experience of teaching this module exposes the pressures on academics to conform to institutional and government expectations regarding how we teach and how we undertake assessment. It is therefore of clear importance to pedagogy and relevant to the professional rewards that academics have a right to expect given their commitment to their disciplines and to their students.

The article outlines changes brought to the module and discusses observations based on evidence regarding the impact of these changes. The conclusion presents a damning indictment of the direction of travel in how academics are obliged to respond to the expectations of institutional management and administration. It is unfortunate that the experience outlined in this case exerts a dispiritingly negative impact on the student experience and staff morale.

\section{Student engagement}

The term student engagement has emerged relatively recently in education debates but is widely deployed in QAA, HEA, Universities UK and in pedagogy literature (Higher Education Academy, 2015; Trowler, 2010; Anyangwe, 2011; Christenson, et al, 2012; Kahu, 2011; Milburn and Shaw, 2017; NSSE, 2013; Sweeney, 2018). This follows a substantial literature around student centred learning (Lea, et al, 2003; Barraket, 2005; Mazur, 1997; Kumar, 2007; Independent Education Today, 2015; Leuven Communiqué, 2009). However, Milburn and Shaw point out that the term lacks any clear definition and its somewhat nebulous character has become embroiled in an instrumental approach to achieving learning outcomes around 'skills development, knowledge acquisition, employability, retention, grades and graduation' (Milburn and Shaw, 2017:54). SE is reduced to measurable outcomes in a process that reflects universities being viewed increasingly as training and accreditation institutions, away from the classical understanding of their centrality in the pursuit of knowledge and understanding through blue sky thinking and reflective analysis. Milburn and Shaw posit two contrasting ways of understanding student engagement:

1. SE as a set of measurable outcomes such as grade point average, degree classification, class attendance and student retention.

2. SE as a difficult-to-measure, holistic and abstract transition that students undergo throughout their HE career (Milburn and Shaw, 2017:54). 
I describe the latter as 'positive student engagement' (Sweeney, 2018:256). Positive student engagement values a cognitive-emotional commitment to a wide range of contextual attributes associated with students' own cultural capital and that of others (Bourdieu, 1980). It supports teaching and learning strategies that depend not only on student-centred learning but on eliciting responses to situations and themes which bring emotional connections to students' experience, their interests and their prospective futures. What matters more than the end-point of study and the award of certification is the process through which students become active lifelong learners able to bring critical and analytical skills to addressing societal concerns. These aspirations ought to underpin the teaching and learning process but in an increasingly competitive, mechanistic, instrumental and measured environment where the type- 1 above holds a dominant position, the idealism of type- 2 seems quaint and unattainable. It is clear too that for students the transformation of the university experience extends to their own priorities being the result: the degree and its classification are the primary if not the sole purpose of going to university. This is probably especially true for parents and sponsors paying the fees. The degree after all is literally marketed and sold as providing the vital route into a rewarding career with pay and perquisites to match.

We turn now to evidence from a module in my university, experience which encapsulates difficulties facing staff needing to confront not untypical challenges in today's universities.

\section{Case study: it wasn't broke, then it was, then what happened?}

The module International Political Economy and Business has long been a core autumn term module in MSc International Business and Strategic Management at The York Management School (TYMS). It was always very popular, achieving high evaluation scores and extremely positive qualitative comments from students, many of whom had never encountered a module so heavily rooted in politics and political theory, in this case International Political Economy (IPE) and International Relations (IR) theory. The module lays down theory in the opening weeks before presenting critical analysis of leading international institutions and a broadly neo-Marxian critique of Neoliberalism, viewed as the driving ideology of contemporary economic globalisation. The core text is the widely used standard introduction to IR, The Globalisation of World Politics (Baylis, Smith and Owens (eds.), OUP 2017).

During a 2016 review of the postgraduate offer in the School, the module was added to the core diet of MSc Management and to two new programmes MSc International Business and MSc International Strategic Management. Every year it also attracts students from MSc Corporate Social Responsibility and Environmental Management, run jointly between Management and the Environment Department. These students add high value to the teaching and learning experience as they hail from various countries adding to cohort 
diversity. They also tend to be well informed and vocal, contributing significantly to class discussions.

Until the 2017 intake around 70 per cent of the usual cohort of between 40 and 60 students on the module came from the Peoples Republic of China (PRC). The other 30 per cent tended to be highly diverse, with often fifteen different countries represented. This added to the enjoyment of teaching this module and no doubt contributed to positive student engagement. A significant number also came from various European Union countries. These too tended to be vocal contributors to class discussions. The style of teaching always involved high levels of student participation, not only in seminars, but also in lectures designed to be as interactive as possible, usually including discussion of contemporary news events.

In 2017-18 the module for the first time took in 85 MSc Management students, the great majority from PRC. This coincided with rapid expansion in the School. There was an alarming fall in the average mark for the assessment (see Table 1). The assessment had consisted of a 3,000-word essay that tested learning of core content from across the module, with the best performing students showing a good level of critical analysis and understanding of theory. Students could choose between two alternative titles. The average score for several years was consistently around 60-61 per cent, just inside 'Merit' category. In 2017 this tumbled to 51 and in a much larger cohort almost half the students failed to reach the pass mark of 50 per cent at M-level. At the top end, as in previous years there were some high performing students producing distinction standard essays, around 10 per cent of the cohort.

The teaching team noticed a marked deterioration in student participation in seminars. This was only partly in terms of attendance, being more a question of students poor preparation and not contributing to discussions. In former years seminars had 10-15 students and never more than 20. In 2017 the average seminar size was often over 20. Tutors noted that many students appeared reluctant to engage, did not contribute and were poorly prepared.

The teaching team discussed these symptoms of declining performance and wanted to address these in ways that could achieve better results, promote better participation and improve student engagement (SE). Several steps were taken to arrest the decline, including:

1. Structural change. We abandoned weekly seminars, having Workshops in Weeks 3, 5, 7, 9 and 10 instead. This change was motivated by poor participation in seminars, including tendency for some students to free ride on others having done the preparation. The seminars had grown too large. We decided to switch to workshops with 30-40 students in each Workshop. We divided the students into self-selecting groups of seven or eight, and these groups would work together throughout the course over the nine-week period. The Workshops being 
fortnightly meant students had more time to prepare. Work was set and publicised in the lectures and on the Virtual Learning Platform at least a week before the scheduled Workshops.

2. Rotating tutors. We introduced a system of three tutors, the module leader delivering most of the weekly lectures and the Workshops delivered on a rotational basis by different tutors for each session. This meant all students saw all three tutors in their workshop at least once.

3. Workshops, each of two hours in large rooms with flexible seating, were carefully planned with set questions linked to readings, around a dozen TRUE/FALSE statements summarising key issues and allowing for discussion and a couple of group presentations from students on a pre-indicated topic. The rest of each workshop consisted of discussion with answers to questions elicited from the various groups.

4. Lectures remained unchanged - 9 weekly 2-hour lectures on Monday preceding Thursday Workshops. They were always highly interactive and supported by PowerPoint slides, subsequently placed on the Virtual Learning Platform with additional content elicited from students during the sessions, Summary audio accompaniment is added. The slides consist of headline topics with 15-20 slides per lecture, bullet points, pictures or diagrams, but not much text. The slides support the lecture, they are not the lecture content.

5. Workshop preparation. We shortened the reading burden. We used targeted readings and provided accompanying worksheets with specific seminar questions related to the specific readings - usually extracts from a book, a chapter from the course book, or news articles or commentaries from the Economist or Financial Times. Worksheets included TRUE/FALSE exercises, What/Why or How type questions, and instructions on preparing a group presentation. We encouraged students to work in their groups to prepare for the Workshops.

6. Assessment. We abandoned the 3,000-word single essay, introducing instead a 10question summative assessment, released in Week 7. Students choose five questions to write short answers of around 500-words each, total assignment length 2,500 words $+/-10 \%$. Answers should show familiarity module readings, workshop material, and the course book. We required a single list of references. Students had six weeks to complete the work, run it through Turnitin and make an electronic, anonymised submission.

We included a formative assessment in Week 8 or 9 whereby students could electronically submit a single page outline of two of their five answers, indicating a basic structure or key bullet points, and identify relevant literature. All students undertook this formative assessment. The final Workshop and half of the final lecture was dedicated to feedback on the formatives although all students received individual electronic feedback as well. 


\subsection{The outcome - results of the changes}

Structural changes and students' module evaluations

Student evaluations of the module - conducted electronically in Week 10 - were positive and comparable with previous years. Students enjoy this module and like how it is delivered. They also profess to find the content interesting and stimulating, according to informal responses, electronic quantitative and qualitative evaluation and reports from Student Representatives to the termly Staff Student Liaison Committee (SSLC). Significantly, students reported finding the workshops rewarding and enjoyable.

We consider the switch to Workshops a success, with better attendance, more participation and a general buzz around the workshops that the seminars had often lacked, especially in 2017. In SSLC we heard that the two-hour workshops gave students more time to prepare, and time was more efficiently spent in a two-hour fortnightly class than in weekly one-hour seminars. Student Representatives suggested the Workshop model be used in other modules.

The more targeted readings were effective and students more regularly got to present findings in the workshops. We felt optimistic about a good level of learning across the cohort.

\subsection{Assessment results}

Many formative assessments were rather poor. Students struggled to follow instructions. We responded by devoting the final week to feedback and guidance for the assessment. Students could ask questions and we gave clear directions on how to answer the questions as set.

Unfortunately, the final assessments were no better than the 2018 essays (see Table 1). This is disappointing as we felt the five-question format was easier. It is a ghastly phrase, but we think we had 'dumbed-down' the assessment. The 500-word answers allow students to display basic content knowledge and learning from across the module, but there is less scope to shine with critical comment or analysis of underlying issues. Despite this the best students managed this to some degree and around ten percent achieved top marks. However, the cohort average remained 51 percent, no improvement and a very disappointing outcome. 
Table 1: Comparison of marks following increased cohort size: note decline in percentages achieving highest marks, increase in fails, and fall in median/average scores after 2017.

\begin{tabular}{|c|c|c|c|c|}
\hline \multicolumn{5}{|c|}{$2018 / 19$} \\
\hline \# of students & Mark range & Median & Average & St. Dev. \\
\hline 196 & $10-90$ & 52 & 51 & 15.65 \\
\hline Distinction & Merit 60-69 & Pass 50-59 & Fail 40-49 & Fail $<40$ \\
\hline $18(9 \%)$ & $49(25 \%)$ & $50(26 \%)$ & $39(20 \%)$ & $40(20 \%)$ \\
\hline \multicolumn{5}{|c|}{$2017 / 18$} \\
\hline \# of students & Mark range & Median & Average & St. Dev. \\
\hline 130 & $0-88$ & 52 & 52 & 16.74 \\
\hline Distinction & Merit 60-69 & Pass 50-59 & Fail 40-49 & Fail $<40$ \\
\hline $18(14 \%)$ & $24(18 \%)$ & $42(32 \%)$ & $24(18 \%)$ & $22(18 \%)$ \\
\hline \multicolumn{5}{|c|}{$2016 / 17$} \\
\hline \# of students & Mark range & Median & Average & St. Dev. \\
\hline 36 & $30-90$ & 60 & 60 & 16.38 \\
\hline Distinction & Merit 60-69 & Pass 50-59 & Fail 40-49 & Fail $<40$ \\
\hline $16(44 \%)$ & $3(8 \%)$ & $5(14 \%)$ & $9(25 \%)$ & $3(8 \%)$ \\
\hline \multicolumn{5}{|c|}{$2015 / 16$} \\
\hline \# of students & Mark range & Median & Average & St. Dev. \\
\hline 40 & $28-88$ & 62 & 61 & 13.95 \\
\hline Distinction & Merit 60-69 & Pass 50-59 & Fail 40-49 & Fail $<40$ \\
\hline $10(25 \%)$ & $13(33 \%)$ & $10(25 \%)$ & $4(10 \%)$ & $3(7 \%)$ \\
\hline \multicolumn{5}{|c|}{$2014 / 15$} \\
\hline \# of students & Mark range & Median & Average & St. Dev. \\
\hline 64 & $10-85$ & 59 & 57 & 14.67 \\
\hline Distinction & Merit 60-69 & Pass 50-59 & Fail 40-49 & Fail $<40$ \\
\hline $14(22 \%)$ & $18(28 \%)$ & $18(28 \%)$ & $8(13 \%)$ & $6(9 \%)$ \\
\hline
\end{tabular}

\section{Conclusion}

The results did not improve even if the teaching and learning experience had felt better than in 2018. We think the 500-word format may disadvantage good and very good students as they have less scope to show deeper learning and critical analysis than in a 3,000-word essay. Some managed this, but the truth is that the new format works to show basic content knowledge, but is less good at bringing out creativity and critical analysis.

We might have accepted this bargain had results at the bottom end been better but this was not the case. The same low average mark was a disappointment. A large number of students simply did not making the grade, not performing at Master's level. They will undertake resits in August by which time they may have adjusted to the demands of the programme and of the university. Significantly, other modules also show marked deterioration in performance. 
Further analysis is required at an institutional level to make a well-informed judgement on the underlying causes of poor student performance. We suspect the decline is due to cohort expansion and the channels the university uses for recruitment. These are questions many HEIs need to confront in an honest and comprehensive debate about standards.

\section{References}

Anyangwe, E. (2011) Live chat: Putting student engagement at the heart of HE. Guardian 11 October. http://theguardian.com/higher-education-network/blog/2011/oct/11/studentengagement-livechat

Barraket, J. (2005) 'Teaching Research Methods Using a student-centred approach? Critical Reflections on Practice'. Journal of University Teaching \& Learning Practice, 2(2) 6474.

Brown, R. and Carasso, H. (2013) Everything for Sale: The Marketisation of UK Higher Education. Abingdon; New York: Routledge.

Christenson, S.L, Reschly, A.L. and Wylie, C. (eds) (2012) Handbook of Research on Student Engagement. New York: Springer.

Collini, S. (2011) From Robbins to McKinsey. London Review of Books. 25 August.

Fielden, J. (2007). Global Horizons for UK Universities. London: The Council for Industry and Higher Education.

Gray, J. (2010) False Dawn: the delusions of global capitalism. Cambridge: Polity.

Higher Education Academy (HEA) (2015) Policy guide - Student engagement [online]. www.hefce.ac.uk/reg/forstudents/sp/se/

HM Government (2010). Browne Report: Securing a Sustainable Future for Higher Education. London: Department of Business, Innovation and Skills. https://www.gov.uk/government/publications/the-browne-report-higher-educationfunding-and-student-finance

HM Government (2011) Higher Education White Paper: Students at the heart of the system. London: Dept. of Business Innovation and Skills. https://www.gov.uk/government/consultations/higher-education-white-paper-studentsat-the-heart-of-the-system

Independent Education Today (2015) 'Student-centred learning improves outcomes and engagement' 23 October. https://ie-today.co.uk/Article/student-centred-learningimproves-outcomes-and-engagement/

Jongloed, B. (2003) Marketisation in higher education, Clark's triangle and the essential ingredients of markets. Higher Education Quarterly 57(2): 110-135.

Kahu, Ella R. (2013) Framing student engagement in higher education, Studies in Higher Education, 38:5, 758-773, DOI: 10.1080/03075079.2011.598505

Knight, J. (1994). Internationalization: elements and checkpoints. Ottawa: Canadian Bureau for International Education.

Knight, J. (2003). 'Updating the definition of internationalization'. International Higher Education. 33, Fall. 
Kumar, A. (2007). Personal, Academic and Career Development in Higher Education. London: Routledge

Lea, Susan J. David Stephenson \& Juliette Troy (2003) Higher Education Students' Attitudes to Student-centred Learning: Beyond 'educational bulimia'?, Studies in Higher Education, 28(3), 321-334, DOI: 10.1080/03075070309293

Leuven Communiqué (2009) Communique of the Conference of European Ministers responsible for Higher Education 28-29 April. http://www.ehea.info/media.ehea.info/file/2009_Leuven_Louvain-laNeuve/06/1/Leuven_Louvain-la-Neuve_Communique_April_2009_595061.pdf

Lynch, K. (2006) Neoliberalism and marketisation: The implications for higher education. European Educational Research Journal 5(1): 1-17.

Mazur, E. (1997). 'Peer Instruction: Getting Students to Think in Class' in E. Redish and J. Rigden (eds) The Changing Role of Physics Departments in Modern Universities: Proceedings ICUP. American Institute of Physics, Conference Proceedings 399: 981 988.

Milburn-Shaw, H. and Walker, D. (2017) 'The Politics of Student Engagement'. Politics. 37(1): 52-66. https://doi.org/10.1177/7026339571562615

Nixon, E., Scullion, R. and Hearn, R. (2016). 'Her majesty the student: marketised higher education and the narcissistic (dis)satisfactions of the student-consumer'. Studies in Higher Education, (0): 1-27. DOI:10.1080/03075079.2016.1196353

Molesworth, M., Nixon, E. and Scullion, R. (2009) Having, being and higher education: The marketisation of the university and the transformation of the student into consumer. Teaching in Higher Education 14(3): 277-287.

Molesworth, M, Scullion, R. and Nixon, E. (eds) (2011) The Marketisation of Higher Education and the Student as Consumer. Abingdon: Routledge.

NSSE (2013) National Survey of Student Engagement: The college student report. http://nsse.iub.edu/pdf/survey instruments/2015/NSSE\%202015\%20\%20US\%20English.pdf

Robinson, Ken (2006) Do Schools Kill Creativity? TED Talk. https://mail.google.com/mail/u/0/\#search/stroudheather\%40aol.com/lLtBPXMsdDpxFV qZgwlnDPGWmHgZRnkWxhdsgCZTDzHpJtwnlvZCXjkgWggqDHJcTmlhLsGc?proj ector $=1$

Sweeney, S. (2012). Going Mobile: Internationalisation, mobility, and the European Higher Education Area. York: Higher Education Academy. https://www.heacademy.ac.uk/system/files/resources/going_mobile.pdf.

Sweeney, S. (2018) 'Student Engagement: Key Skills, Social Capital, and Encouraging Learner Contributions to Module Resources' Journal of Contemporary European Research 14(3): 253-272. https://doi.org/10.30950/jcer.v14i3.899

Trowler, V. (2010) Student Engagement Literature Review. Higher Education Authority. www.lancaster.ac.uk/staff/trowler/StudentEngagementLiteratureReview.pdf

Warner, M. (2015). 'Learning my Lesson: Marina Warner on the disfiguring of higher education'. London Review of Books, 37(6): 8-14. 